\title{
STATE, REPRESENTATIVE INSTITUTIONS AND ECONOMIC REFORMS IN TIMES OF DECLINE: \\ ROYAL TAXATION AND TRADE POLICY IN ARAGON (1626-1700)
}

\begin{abstract}
This article explores fiscal and trade policy in Aragon between 1626 and 1700, providing a case study of economic management by regional institutions in a composite monarchy of the early modern period. The increasing burden and irregular distribution of royal taxation hastened economic decline in seventeenth century Aragon. Eventually, the monarchy moderated its fiscal demands in 1678-97 to alleviate the financial distress of the region's towns and villages and cure the economic ills caused by protectionist trade policies in north-eastern Spain. The Aragonese Parliament only lowered royal subsidies after 1678, though it began to raise import duties as early as 1626 to ease the pressure on heavily indebted municipal treasuries. However, conflicting regional interest groups undermined the Cortes' economic policies, and their main effect was to drive up transaction costs without preventing French control of trade and manufacturing in Aragon in the second half of the seventeenth century. In contrast, the free-trade policies pursued by the Diputación were more consistently applied and enjoyed greater legal and political support, fostering export-led agricultural specialization from which the elites were able to profit, although they failed to deliver long-run economic growth.
\end{abstract}

\section{Introduction.}

Throughout the nineteenth century and for much of the twentieth, historians, sociologists and economists sought to explain Europe's dominance over the rest of the world, which was believed to be rooted in the political, economic and social transformations wrought in the preceding centuries, and especially in the growing power of the state in the early modern period. Countless scholars essayed empirical studies at the national level, and this interest eventually materialised in the theories propounded by the economist Joseph Schumpeter and the sociologist Max Weber between 1918 and 1920 with regard to the new functions assumed by the state and its contribution to European history. Weber focused on political and administrative centralisation through the creation of a large, efficient bureaucracy supported by the 
legal monopoly of force. Schumpeter stressed the fiscal orientation of the early modern state, a corollary of its hunger for funds to finance incessant military campaigning. This "fiscal state", in which the realm as a whole contributed to fund the actions of the monarchy, gradually evolved from a system, the "domain state", based solely on the resources that could be obtained from the monarch's personal domains. Both Schumpeter and Weber believed not only that the fiscal state diminished the power wielded by the feudal aristocracy and regional or local institutions in the Middle Ages, but also that it fostered the transition to market economies capable of providing more sustained growth, underpinning the rise of capitalism and liberal government in modern Europe. These ideas took firm hold in Europe, favoured by state intervention in national economies in response to the crash of 1929 and the two world wars. Many of the theories proposed by historians and sociologists in 1950-75 to explain political and economic developments in nineteenth- and twentieth century Europe thus stressed the importance of political and fiscal centralisation in the early modern period, which the state was able to impose on both elites and institutions thanks to its growing coercive power. ${ }^{1}$

However, the crucial role assigned by European historiography to the political centralisation of the state has been revised by sociologists and historians alike since 1975. Taking Weber as their starting point, historical sociologists like Tilly, Mann and Downing sought to relate the absolutist or parliamentary structure of each state and the size of its bureaucracy with fiscal policies and the military pressures caused by the frequent strife between nations in the early modern period. Influenced by Marxism, Anderson argued that the absolutist state represented a reorganisation of feudalism in the service of the agrarian elites, and that its specific features were defined by regional differences in economic and social structures. Political historians and historical sociologists now generally accept that a gradual process of state-building took place between the late mediaeval and the early modern period, and numerous published works describe how rulers sought the political cooperation of regional elites by integrating their interests with those of the state. This strategy encouraged patronage and clientelism in appointments to public office, hindering the creation of an efficient bureaucracy in the exclusive service of the state. ${ }^{2}$ 
Later economic historians have revised Schumpeter's fiscally oriented description of the early modern state, placing the emphasis on overall economic management. On this view, increasingly fierce military and trade rivalries in early modern Europe obliged the new state not only to tax its subjects more efficiently, but also to improve institutional conditions for production and trade, and to organize natural and human resources so as to achieve steady long-run growth. ${ }^{3}$ It was the proponents of the New Institutional Economics who reopened the debate, first raised by historical sociologists, with regard to the state structures which might have favoured this process. Where Weber and Tilly argued that the absolutist states taxed their subjects excessively, especially in the cities, North and Weingast add that the absence of institutional checks made them more likely to adopt economic policies that hampered growth. In contrast, they claim, the English revolution of 1688 not only handed Parliament power over state taxation but also allowed it to hold the monarchy to its commitments in matters of property and other rights, which greatly increased institutional control over royal governance in Great Britain and helped drive growth. Zanden, Buringh and Bosker have recently expanded this theory by linking north-western Europe's more robust parliamentary systems to the region's economic ascendancy over southern and central Europe. However, Epstein has argued that the key process was the concentration of sovereignty by the modern state in Europe. Multiple or composite sovereignties were constrained by the differing degrees of political control they could exercise over their domains, and they were less well able than the centralised state to construct an efficient fiscal policy without increasing transaction costs or deranging market coordination by usurping feudal and corporate rights. ${ }^{4}$

Historians and economists engaging in this debate since 1975 have contrasted fiscal developments in England and Holland, the European states in which parliamentarianism is generally held to have triumphed in the early modern period, and in the absolutist states of France and Spain. Economic management by parliaments and other representative institutions was assessed in terms of the effectiveness of tax systems. ${ }^{5}$ This approach could be fruitfully applied to the heartlands of the state where absolutism or parliamentarianism took hold quickly, and to peripheral territories that were largely beholden to the seat of power. However, it proved problematic in other regions where the new absolutist and parliamentary states, and their representative institutions wielded only partial political and economic control. ${ }^{6}$ According to recent 
research, regional institutions played an important mediating role even in absolute monarchies like France, cooperating with the State during the slow advance of political centralization. $^{7}$ In the peripheral regions of composite monarchies like that of Spain they sought, with differing degrees of success, to uphold traditional political autonomy and keep state taxes low. ${ }^{8}$ However, the economic policies adopted by regional institutions have remained largely unexplored, even though their effects were sometimes far from local.

This paper contributes to the debate on the political development of the state and economic management by regional representative institutions in early modern Europe by examining state taxation and trade policy in seventeenth century Aragon, an autonomous region forming part of the composite monarchy that was Hapsburg Spain. Located in the north-east of the Iberian Peninsula (see map), the Kingdom of Aragon was part of the Crown of Aragon, a federation of realms that coalesced in the late medieval period and also included Catalonia, Valencia, the Balearic Islands, Sardinia, Sicily and Naples. Though it formed part of the nascent Spanish State which grew out of the union of the Crowns of Castile and Aragon under a single dynasty at the end of the fifteenth century, the Kingdom of Aragon retained its own fueros (customary laws) and institutions under the Hapsburg dynasty until their abolition by the new Bourbon monarchy in 1707. As we shall see, the region's institutions enjoyed broader powers to set economic policy than any other Spanish territory of the Crown of Aragon.

Entangled in an endless series of wars with France to defend its political hegemony and territorial control in Europe, the Spanish monarchy imposed a series of trade and tax measures in Aragon beginning in 1626. However, the state could only levy royal taxes with the permission of the most important of the region's representative institutions, the Aragonese Parliament or Cortes. The four estamentos or estates (high nobility, minor nobility, church and citizens) could negotiate new laws at the Cortes and lay their complaints and petitions before the Spanish king. However, Parliaments were convened at ever longer intervals from the mid-sixteenth century onwards. This increased the power of the Diputación de Aragón, a standing committee of the Parliament formed by two representatives from each estamento, which was charged with day-to-day governance of the Kingdom and upholding its customary laws. 
The regional parliaments and Diputaciones of north-eastern Spain enjoyed considerable autonomy in mediaeval and early modern times, and research into these institutions proliferated on the back of the nationalist movements which re-emerged in Spain at the end of the Franco dictatorship and in response to political decentralization by the nascent democratic regime in the 1970s and 80s. Given the extant historical and legal sources, scholars have tended to focus rather on the political and legislative functions of regional institutions than on economic management, particularly in the Crown of Aragon. ${ }^{9}$ As this article will show, the main tax and trade reforms enacted in Aragon in the seventeenth century emerged from a process of negotiation and conflict between the region's representative institutions and the monarchy, which provided the context for intense economic debate between 1674 and 1686. Exploration of the contemporary fiscal and trade debate will throw light on the policies and interests of the Spanish State, the Aragonese Parliament and the Diputación, and on outcomes in a regional economy undergoing painful restructuring. Unfortunately, comparison between the different regions of north-eastern Spain in the seventeenth century is greatly complicated by the divergences between local economies and economic policies, not to mention the patchiness of primary and secondary sources. Consequently, only selected information on Catalonia and Valencia is presented to identify common processes and to highlight certain idiosyncrasies in the case of Aragon.

Overall, we may conclude that regional representative institutions in early modern composite monarchies did indeed have the power to win advantages for local economies in the face of new tax and trade policies imposed by the centralizing state, but they could not by themselves deliver stable long-run growth. Nevertheless, the Spanish monarchy was in fact successful in raising state taxes, if less consistently and effectively than at the political centre, and it was prepared to adapt where new measures adversely affected trade between its dominions, which was increasingly based on regional specialization after 1650 .

2. Demography and economy of seventeenth-century Aragon

Aside from the fiscal demands of the Spanish State, tax and trade policy and debate in Aragon were driven by demographic and economic changes in the 
seventeenth century. In contrast to the population growth it had enjoyed in the second half of the sixteenth century, the region faced serious decline in the seventeenth. King Philip III precipitated this process when he ordered the expulsion of the Moriscos (formerly Muslim inhabitants of Moorish origin, who had been forcibly converted to Christianity in 1526). Around 14,000 families or 18.85 per cent of Aragon's population were driven out in 1610. Even so, a general survey of Aragon performed between 1646 and 1650 found some 70,729 hearths or around 318,280 inhabitants compared to 51,540 hearths or approximately 231,930 inhabitants counted in a similar survey carried out in 1495. However, the bubonic plague ravaged the whole region in 1648-54, and the Cortes estimated that only about 60,000 hearths remained in 1677. Population growth only recommenced in the last two decades of the seventeenth century, and Aragon again had 76,613 hearths or approximately 344,785 inhabitants by $1711^{10}$

The expulsion of the Moriscos caused serious economic problems, beginning with an abrupt fall in output, investment and demand. Trade networks were affected and townships were obliged to assume the debts of their Morisco communities. Furthermore, the Moriscos were mainly the vassals of lay lords, and their exodus drastically reduced feudal rents, aggravating the financial distress of the high nobility, which in turn depressed consumption of luxury goods and hurt the credit system, choking off investment. ${ }^{11}$ The erosion of credit can be discerned in the reaction of the municipalities' creditors (mainly citizens and petty nobles), who increasingly sold or donated claims to the church, including loans made to the traditionally more solvent royal boroughs, thereby transferring the risk of default or steep falls in interest rates. These fears were confirmed by a wave of municipal bankruptcies beginning in the villages and finally spreading to the larger towns after 1650, which caused cuts in interest rates from the usual 5 per cent to 3 per cent or less. ${ }^{12}$ Moreover, the financial distress of the nobility and the municipalities squeezed the credit offered by the rentier classes, driving up the cost of short-term loans. In an effort to rein in the all-toocommon practice of usury, the Diputación proposed fixing the interest rate at 7.5 per cent at the Cortes of $1626 .^{13}$

The erosion of credit and investment was initially triggered by the financial collapse of the commercial bourgeoisie around 1580. Neither the Genoese merchant colony, which controlled trade in Aragon until 1620, nor the French, who had created an extensive trade network and effectively took over for the rest of the seventeenth 
century, were much interested in financing Aragonese manufacturing. ${ }^{14}$ The French specialized in importing manufactures, particularly cloth and lace, which accounted for 29.77 and 21.91 per cent of regional imports from France in 1675. They also exported wheat and oil to Catalonia and, especially, wool to France, where demand was so intense that this commodity accounted for 77.95 per cent of all Aragonese exports to its neighbour in $1675 .{ }^{15}$ To obtain these products, French merchants would lease the rights to collect seigniorial rents, tithes and first fruits from the lay and ecclesiastical lordships of Aragon. However, they did not engage in long-term lending or buy land or livestock.

The growth of French commercial networks after 1620, which included artisans and tradesmen, further increased their control over retail trade in both urban and rural areas, and by the end of the seventeenth century some traders were even operating as the representatives of other merchants established in the towns of southern France, who exported goods to Aragon either directly or via the Kingdom of Navarre. ${ }^{16}$ Meanwhile, the Aragonese bourgeoisie largely turned their backs on commerce as they gradually recovered from bankruptcy in the second half of the seventeenth century, preferring instead to buy land from indebted nobles, lease property and lend to the Spanish monarchy, but their recovery was not strong enough to crowd out the French. ${ }^{17}$

The Aragonese textile guilds experienced serious capital shortages and technological stagnation in the seventeenth century, and their products became ever less competitive, especially after 1650. Meanwhile, the expansion of French trading precipitated decline through mass imports of cheaper, better quality goods from France. The number of textile workshops fell by 42.10 per cent in Barbastro between 1619 and 1680, and by 51.10 per cent in Saragossa between 1642 and 1721. The reports prepared by the councils of Calcena, Caspe, Daroca, Alcañiz and Albarracín as part of an investigation ordered by the Diputación in 1667 show a similar fall in textile output. In Calcena the council estimated that only 200 of the 400 families engaged in the woollens industry in 1640 were still employed by 1667 . This decline prompted some expansion of textiles-making in rural areas, but only to produce poor quality stuff for local consumption, which could not compete in wider markets. ${ }^{18}$

The bankruptcy of the Aragonese bourgeoisie and the decline in local industrial and craft output allowed French merchants and manufactured goods to take over in the second half of the seventeenth century. At this time, the regional economy became increasingly oriented to the production and export of wool, wheat, olive oil and meat as 
demographic decline depressed domestic demand, while the appetite of France, Valencia and Catalonia for Aragonese commodities grew ever stronger. In this context, farmers tried increasingly to align their production with the changing patterns of foreign and domestic demand, as the competition for markets intensified. Thus, the incipient local specialisation already discernible in the sixteenth century gathered pace after 1650 , consolidating comparative advantages in trade. ${ }^{19}$ There was no serious effort to improve the productivity of the land, however. Burdened with debt and lacking the means of production in the countryside, many landowners, merchants and money lenders preferred simply to deprive the peasants of their surpluses as an easier way to

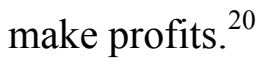

\section{Royal taxation in Aragon}

3.1. The traditional pattern: royal taxation in the sixteenth century.

In urgent need of more regular subsidies to finance military campaigns, the Spanish monarchy sought in the seventeenth century to modify the basic pattern of royal taxation in Aragon, which had developed out of the stable procedure established for the collection of royal subsidies under the reign of Ferdinand the Catholic (1479-1516). In the late Middle Ages, the king would apply to the Aragonese Parliament either for funds or for levies of fully equipped, paid troops, but after 1518 the monarchy only sought cash subsidies to pay the cost of raising and maintaining professional armies. The Cortes of 1510 set the subsidy at 200,000 libras payable over three years. Of this total, 156,000 libras (78 per cent) were paid by the municipalities, and the Diputación contracted loans to defray the remaining 44,000 libras (22 per cent). Significantly, the "ordinary" subsidy granted in 1510 was renewed by all of the Parliaments convened by the Hapsburg monarchy until the end of the sixteenth century, sometimes accompanied by "extraordinary" subsidies, which ranged between 19,000 and 100,000 libras. As in Catalonia and Valencia, the "ordinary" subsidies voted by the Parliaments of Aragon stagnated in the sixteenth century. However, the Cortes agreed to pay 400,000 libras in 1585 , and it voted a further 700,000 libras in 1592 as a result of severe pressure after the Spanish monarchy had snuffed out an Aragonese rebellion against royal power in 1591 (see Table 1). These "extraordinary" subsidies were paid exclusively by the Diputación, 
which again contracted loans. Exceptionally, the monarchy also raised modest "donations" from the Aragonese municipalities to defend the Crown of Aragon against the threat of foreign invasion or local rebellion. ${ }^{21}$

Table 1

Royal cash subsidies approved by the Aragonese Cortes in the sixteenth and seventeenth centuries (in libras)

$\begin{array}{cccccccc}\begin{array}{c}\text { Year } \\ \text { granted }\end{array} & \begin{array}{c}\text { Total } \\ \text { amount }\end{array} & \begin{array}{c}\text { Collection } \\ \text { period }\end{array} & \begin{array}{c}\text { Annual } \\ \text { amount }\end{array} & \begin{array}{c}\text { Year } \\ \text { granted }\end{array} & \begin{array}{c}\text { Total } \\ \text { amount }\end{array} & \begin{array}{c}\text { Collection } \\ \text { period } \\ \text { three years }\end{array} & \begin{array}{c}\text { Annual } \\ \text { amount }\end{array} \\ 1510 & 219,000 & \text { three years } & 73,000 & 1564 & 250,000 & \text { the } \\ 1518 & 200,000 & \text { three years } & 66,000 & 1585 & 400,000 & \text { three years } & 133,333.3 \\ 1528 & 200,000 & \text { three years } & 66,666.6 & 1592 & 700,000 & \text { three years } & 233,333.3 \\ 1533 & 200,000 & \text { three years } & 66,666.6 & 1626 & 2,160,000 & \begin{array}{c}\text { fifteen } \\ \text { years }\end{array} & 144,000 \\ & & & & & & \text { four years } & 144,000 \\ 1537 & 200,000 & \text { three years } & 66,666.6 & 1646 & 576,000 & \text { fours } \\ 1542 & 300,000 & \text { three years } & 100,000 & 1678 & 451,296 & \text { eight years } & 56,412 \\ 1547 & 222,000 & \text { three years } & 74,000 & 1686 & 402,000 & \begin{array}{c}\text { twelve } \\ \text { years }\end{array} & 33,500 \\ & & & & & & \text { years }\end{array}$

Sources: Blanco, La actuación, 67-68; Savall and Penen, Fueros, I, 474-476, 526-527; II, 370, 402.

Note: The libra was a monetary unit of account equal to twenty sueldos. After the change to Castilian standards of weight and fineness in all silver issues from 1519 onwards, one sueldo equalled half a real, the basic silver coin minted in Aragon in the sixteenth and seventeenth centuries.

Despite the contribution from the Diputación, royal subsidies in the sixteenth century depended largely on municipal levies, which were calculated based on the number of hearths (qua fiscal units) according to the census of 1495, applying a different tax rate per unit for towns, villages with more than one hundred hearths and villages with less. The terms of every royal subsidy approved by the Cortes in the sixteenth century allowed town and village councils to apply for three-year sisas reales or special taxes on basic foodstuffs, especially grain and meat, on behalf of the royal exchequer. However, the Parliament always permitted councils to choose the specific taxes they would raise to pay the royal subsidy. The towns and cities normally applied sisas, but rural settlements, where the communal tradition had deep roots, mostly preferred direct taxation in the form of poll taxes. Every social group had to pay these royal taxes, including the clergy and nobility. ${ }^{22}$ 
Figure 1

Customs revenues of the Aragonese Diputación (1501-1701) (in libras)

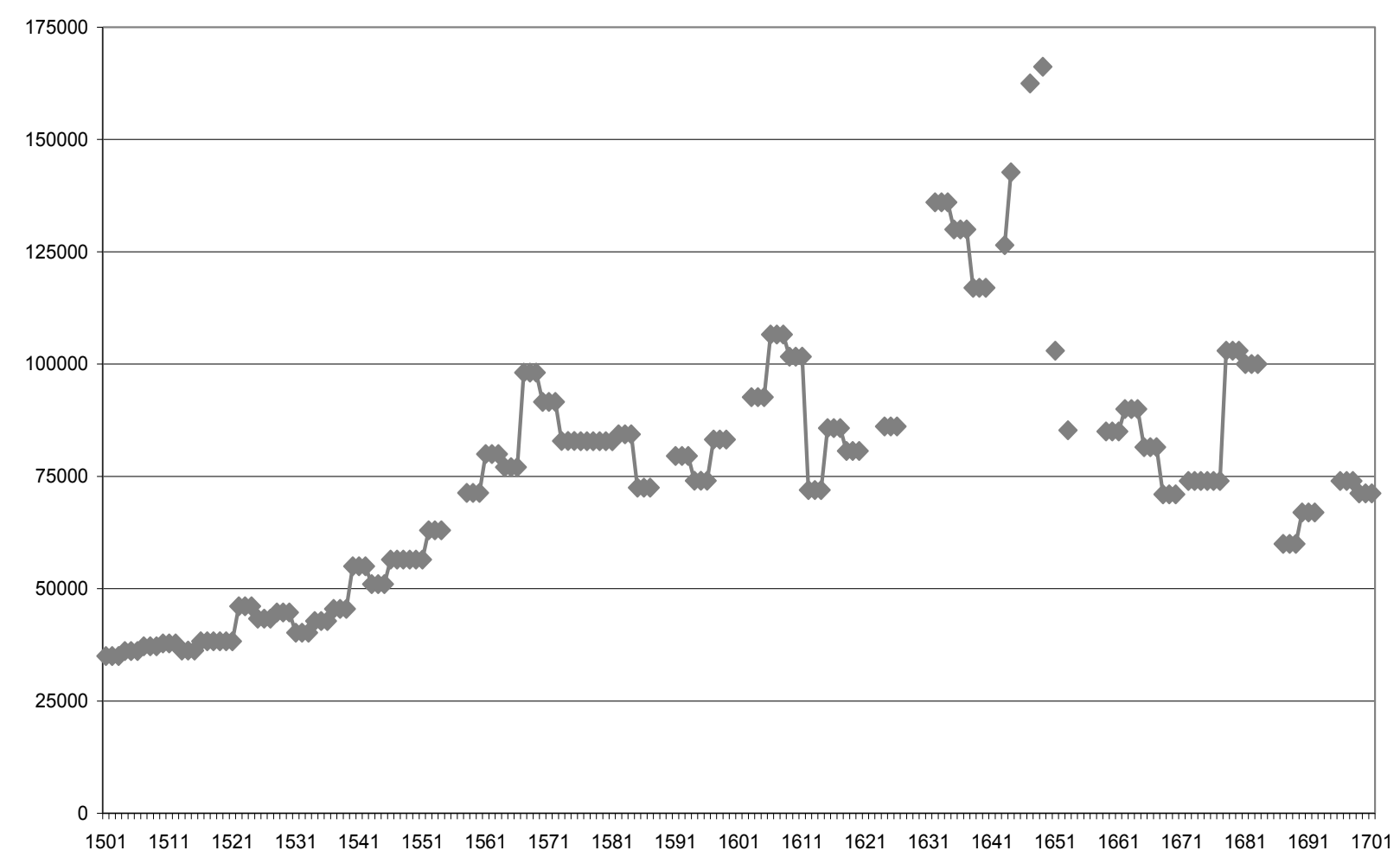

Sources: Colás and Salas, Aragón, 43; Gómez Zorraquino, La burguesía mercantil, 228229 and ADS, Manuscripts 445, fos.85v-87v; 449, fos.107r-108r; 460, fos.1r-8r; 469, fos.62r63r; 477, fos.111v-113r; 483, fos.107r-109r; 511, fos.1r-6r; 512, fos.1r-4r; 535, fos.2r -6r; fos.3r-6v; 552, fos.1r-6r; 563, fos.1r-8r; 599, fos.1r -6r; 600, fos.3v-7r; 609, fos.1r-6r ; 625, fos.1r-6r and LSRAH, Collection Nassarre, 11/7,946

Note: Extant records of the Diputación's revenues for the periods 1628-42 and 1678-86 include the 5 per cent tax on the value of textiles produced.

These arrangements for the collection of royal subsidies were conceived for a realm where the Cortes met regularly and could vote badly needed funds for the sempiternally empty royal purse, given the exchequer's scant revenues in Aragon. As an illustration of these financial difficulties, the Spanish monarchy agreed in the sixteenth century to apply 44.44 per cent of the royal taxes paid by towns and villages to settle debts and salary arrears incurred by the royal bureaucracy in Aragon. The Emperor Charles V respected this system, convening regular Cortes throughout his reign (1516-58), but his son Philip II, an altogether more centralising monarch, began to change the pattern of royal taxation, convening fewer Parliaments in his reign (155898) while seizing the opportunity presented by Aragon's economic expansion in the 
second half of sixteenth century (see Figure 1) to make repeated demands for large "extraordinary" subsidies to compensate for the declining frequency of the Parliaments at which royal subsidies were ordinarily voted (see Table 1$){ }^{23}$

In contrast to Castile, the continuation of "ordinary" subsidies and the longer periods between Cortes actually lowered the burden of royal taxes in Aragon, Catalonia and Valencia. This allowed the Aragonese municipalities to increase their borrowing, and hence their spending, especially in the second half of the sixteenth century. As well as maintaining the local administration and splurging on ever more lavish fiestas and civic ceremonies, councils were able to improve the public food supply, undertake public works and expand irrigation systems. Low state taxes also allowed the Diputación to hold down the customs duties charged at the region's borders and in the larger towns, which were the main source of its revenues. These moderate tariffs (generally 5 per cent of the value of goods) favoured trade in sixteenth century Aragon, especially after 1550, and this growth was reflected in higher customs revenues (see Figure 1). Having assured the upkeep of its bureaucracy, the Diputación used a part of its revenues to help found the university of Saragossa in 1582-84 and, especially, to pay for the repression of banditry and to build or repair bridges and roads along the vital trade routes linking northern Aragon with France between 1560 and $1626 .^{24}$

\subsection{Royal taxation in the seventeenth century.}

Fiscal policy underwent a crisis in the seventeenth century, as the Spanish monarchy spaced out meetings of the Castilian and Aragonese Parliaments even further while actively seeking revenue sources that did not need to be voted, such as new monopolies and depreciation of the coinage. From the middle of the sixteenth century, only the main cities were represented in the Castilian Cortes, and the monarchy increasingly resorted to direct negotiation of royal taxes with their representatives in the seventeenth century until the last Parliament was convened in 1665 . However, the Parliaments of Catalonia, Valencia and Aragon were formed by representatives of the municipalities, the nobility and the clergy, which made negotiation much more complex. As a result of the bellicose policy pursued by the Count-Duke of Olivares, the favourite or valido of Philip IV, the monarchy sought greater fiscal cooperation from the Crown of Aragon to help finance its involvement in the Thirty Years' War (161848) through the planned Unión de Armas or Military Union. The monarchy's initial 
strategy was to seek a larger annual subsidy over a longer term than had been the case in the sixteenth century. However, the contribution demanded by Philip IV in 1626 met with determined opposition from the delegates of the Aragonese municipalities and the nobility of Valencia, and it was flatly rejected by all the estamentos in Catalonia. This opposition marked the beginning of a period of political discord between the principality and the Hapsburg monarchy, which ended in revolt and temporary secession in $1640-52 .^{25}$

The monarchy suddenly began to demand larger and more regular subsidies from Aragon between 1626 and 1652 as part of its last ditch effort to defend political and military hegemony in Europe during the reign of King Philip IV (1621-65). However, the revenues of the royal exchequer in Aragon were barely enough to keep the state bureaucracy working in the region, and any further increase was impossible. Therefore, these funds had to be raised through the grant of an enormous war chest by the Cortes of $1626 .{ }^{26}$ This royal request immediately split the four estamentos represented in the Aragonese Parliament. Opposed by the citizens, it was immediately supported by the clergy, and the high and low nobility, who were keen to curry favour with the monarch to win access to government offices and ensure their participation in the emerging Spanish state. These elites were far more successful than their peers in the Valencian Parliament in their efforts to reserve permanent posts in the royal councils and in the administration of the American colonies for Aragonese naturals at the Cortes of 1626 and again in 1645-46. The stiff resistance put up by the citizens in the Parliament of 1626 was eventually broken by pressure and bribes, although the initial subsidy was eventually reduced by some 40 per cent. Nevertheless, it was still twice the sum granted by the Valencian Parliament of 1626 for an identical period of fifteen years. Indeed, the total of 2,160,000 libras approved in 1626, payable in annual instalments of 144,000 libras between 1628 and 1642, almost equalled the sum of all "ordinary" and "extraordinary" subsidies voted by the Aragonese Cortes between 1518 and 1585 (see Table 1). The obsolete census of 1495 was used to decide how the royal taxes would be shared among the municipalities until a new census could be prepared on the instructions of the Cortes in 1646-50. ${ }^{27}$

New taxes would be levied on Aragon as a result of the outbreak of hostilities between Spain and France in 1635 and the 1640 uprising against Philip IV in Catalonia, 
which prompted the invasion of western Aragon by a Franco-Catalan army in 1641-43. Loyalty to the monarch and the defence of the realm facilitated the acquiescence of the regional elites, who agreed at the extraordinary assemblies of the estamentos held in 1641-45 to raise local militias and to share the cost of maintaining these troops among the towns without parliamentary approval. ${ }^{28}$ In addition, town and village councils had to foot the bill for the royal army billeted in Aragon. The costs incurred between 1626 and 1646 amounted to more than 2,000,000 libras according to the estimates of the citizens at the Cortes of 1645-46. With the inducement of fresh royal favours and offices for the regional elites, this Parliament extended the annual subsidy of 144,000 libras granted in 1626 for a further four years (1647-50) in order to support the regional militias recruited for the war in Catalonia. In contrast, the Cortes of Valencia had granted just 57,600 libras per annum over a period of six years in 1645, although the kingdom's taxpaying population was only 13.30 per cent smaller than Aragon's in $1646-50 .^{29}$ In return for extending the subsidy, the Aragonese Cortes agreed to exempt the municipalities from any liability for billeting the royal army throughout the period of the subsidy, as it would do again in $1677-78 .^{30}$

The traditional method of collecting revenues via municipal taxes, which had existed since the thirteenth century and became fixed in 1495, proved unequal to the increase in royal taxation because of the financial distress of Aragon's town and village councils in the seventeenth century. Already unable to raise sufficient revenues to tackle the growth in their expenditure in the second half of the sixteenth century, the councils' situation only worsened in the seventeenth until even the perpetual recourse to contract credit became insufficient, forcing the municipalities to seek ever more frequent deferrals and cuts in interest charges from the end of the sixteenth century. As councils slid inexorably towards bankruptcy, these arrangements gradually handed the management of municipal treasuries over to administrators appointed by boards of creditors dominated by the clergy in return for assurances that the local political and legal administration would be maintained, as well as municipal and communal assets. ${ }^{31}$

Given the parlous state of municipal finances, the Cortes of 1626 opted to transfer a larger share of the burden of royal taxes to the Diputación despite the fall in customs revenues caused by the decline in Aragon's trade (see Figure 1), making it necessary to approve new duties and taxes on domestic textile production for the 15 -year term of the 
subsidy. In the end, the municipalities paid only 59.15 per cent of the annual charge between 1628 and 1638. However, in 1639-42 the municipal share soared to 84.19 per cent, as the Diputación's financial surpluses were eaten away by interest payments on outstanding loans and the loss of revenues caused by the temporary closure of the French border on the orders of the Spanish monarchy in 1635. Under intense royal pressure, the Diputación continued to hand over its surpluses to the state treasury in the form of "donations" or advances on unpaid municipal contributions during the critical years of the war in Catalonia. Meanwhile, the Cortes of 1645-46 again boosted the institution's revenues to contain its debt, allowing the tax on textiles production to lapse but raising customs duties in 1647-50. After providing for the defence of Catalonia in 1654-56, the Diputación continued to grant smaller donations for the rest of the seventeenth century. ${ }^{32}$

Having obtained military cooperation from the Cortes of Aragon and Valencia held in 1645-46, while the Catalan conflict was at its height, the monarchy did not again convene the Parliaments of either Valencia or Catalonia for the rest of the seventeenth century, mainly because of the difficulty of wringing regular subsidies out of the estamentos and concern to avoid complaints about increasing royal interference in elections to public office in the Crown of Aragon. ${ }^{33}$ Instead, royal delegates raised loans and military levies directly from the regional elites and institutions in exchange for modest economic reforms and privileges, honours and government office. Councils formed by representatives of the estates or the nobility were created to negotiate with the royal delegates at this time, although they were never vested with legislative powers. Only Aragon succeeded in convening its Cortes in 1677-78 thanks to the influence at court of the bastard son of Philip IV, Don Juan José de Austria, who was keen to requite the strong political support he received in the region while he was viceroy $(1669-75) .^{34}$

The Cortes of 1678 were keenly aware that even the main towns and cities of Aragon were teetering on the edge of bankruptcy, and accordingly they voted a twentyyear subsidy to maintain regional troops for an annual sum of 56,412 libras, just 39.18 per cent of the amount approved in 1646, even though the taxpaying population had shrunk by only 15.15 per cent between 1646 and 1677 (see Table 1). As the necessary funds could not be efficiently raised through municipal taxes, the Parliament doubled 
customs duties and the tax on textiles production was restored. By voting smaller subsidies, however, the Aragonese elites saw their hopes of greater participation in the state and colonial administration dashed. Having allied itself with Holland and the Austrian Empire to fight France in 1673-78, the Spanish monarchy was under less pressure from its foreign wars than it had been during the Cortes of 1626 and 1645-46. The monarchy therefore confirmed the fueros approved by previous Parliaments at the Cortes of 1678, permanently reserving certain posts for the Aragonese elites in the administration, but it hardly granted any new offices. ${ }^{35}$ The influence of Don Juan José de Austria as prime minister of Spain in 1677-79 ensured titles and appointments to important offices at court for some Aragonese nobles, but no positions were permanently reserved for Aragonese naturals. ${ }^{36}$

The fiscal reforms approved in 1678 hurt legal trade and industry and, as provided by the Cortes of 1677-78, delegates from all four estamentos gathered in a special assembly vested with legislative powers in 1684-86 to negotiate with royal delegates. Acting in lieu of a new Parliament, the assembly cut the annual subsidy granted in 1678 by 40.6 per cent, setting it at just 33,500 libras (see Table 1), given the difficulty of collecting the sums required and as a necessary step to reverse the hike in customs duties. New monopolies on salt and tobacco were temporarily established to help pay the subsidy. ${ }^{37}$ These two monopolies, which had existed in the Crown of Castile since 1564 and 1636 respectively, were created partly because the resulting revenues were easier and cheaper to collect than customs duties, and partly because the Hapsburg monarchy was keen to extend its control over the markets for tobacco and salt throughout north-eastern Spain. Not without resistance, the Bourbon monarchy succeeded in imposing these lucrative monopolies permanently throughout the Spanish regions of the former Crown of Aragon in the eighteenth century.

The arrangements with creditors made by town and village councils were discussed at the Cortes of 1626 and from the mid-seventeenth century onwards they required royal consent. This was provided by the privy Council of Aragon, which assisted the monarch in Madrid with political, legal and fiscal issues affecting the Spanish dominions of the Crown of Aragon. Hence, the Spanish monarchy was perfectly well informed about the financial straits of the region's municipalities. ${ }^{38}$ Nevertheless, Kings Philip IV and Charles II demanded constant "donations", as they 
also did in Catalonia and Valencia. Loans worth more than 2,050,000 libras and significant levies of local militias were extracted from the Aragonese capital, Saragossa, between 1629 and 1686, when the city finally sank into bankruptcy. Only moderate donations and levies were obtained from the other towns of Aragon between the end of the war in Catalonia in 1652 and the renewed invasion by the French in 1694-97, except during the government of the viceroy Don Juan José de Austria, who succeeded in raising the contributions levied from both institutions and private taxpayers. $^{39}$

As in the cases of Catalonia and Valencia, it is not possible to trace exactly the development of royal taxation in seventeenth century Aragon for want of accurate information on the total loans and donations made by the Diputación and the municipalities, and on the cost of recruiting and billeting troops in the region. However, the repeated use of such fiscal measures and the longer subsidies granted by the Cortes would unquestionably have increased the burden compared to the preceding century. This taxation was particularly intense in 1628-52, forcing the municipalities to raise their own taxes, which were levied preferentially on domestic consumption of basic foodstuffs like grain and meat in the larger towns. This indirect municipal taxation eroded the working capital, savings and self-financing capacity of the productive classes, while depressing disposable incomes among the population at large. ${ }^{40}$ However, customs duties were also raised to help pay subsidies from 1626 onwards, and the rising tide of municipal debt imposed some moderation on royal taxation after 1652. Finally, these fiscal policies affected prices and therefore the region's economy, which underwent profound restructuring throughout the seventeenth century.

4. Fiscal and economic debate in seventeenth century Aragon

\subsection{The Diputación and support for traditional free trade policies}

The ongoing restructuring of the economy intensified the tussle for control of trade policy between the Spanish State and the Aragonese institutions. Spain fought five full-scale wars against France in the seventeenth century (1635-59, 1667-68, 1673$78,1683-84,1689-97)$, and each time the Spanish monarchy ordered the end of all trade between Aragon and its neighbour in order to stop the French from selling their 
manufactures across the Pyrenees while taking home Spanish silver and Aragonese commodities. Trade was even banned in 1662, when France and Spain were nominally at peace. The Spanish monarchy also ordered the seizure of property belonging to French immigrants, including naturalised residents.

These measures were opposed tooth and nail by the Diputación, which argued that the interruption of trade with France would be detrimental both to the Aragonese economy and to its own fiscal interest, which depended largely on the customs duties raised along the Pyrenean border. This institution was responsible for upholding the kingdom's customary laws, which included the freedom to trade (sanctioned by the Aragonese Parliament since the late medieval period) and placed naturalised immigrants under royal protection. Accordingly, the Diputación held that the royal orders banning trade and seizing French property were unlawful and it appealed on several occasions to the Corte del Justicia de Aragón. Chaired by the Justicia, the principal magistrate empowered to judge legal conflicts between the monarchy and its subjects in Aragon, this court was charged with guaranteeing the fueros, which consisted of local rights and charters granted by the king to the municipalities since the eleventh century. The fueros had been compiled with acts of the Aragonese Parliament since 1247, and this corpus formed the dominant legal system in the region until its abolition in 1707. The court found in favour of the Diputación in 1674.

Following this victory, the Diputación put up determined legal resistance to similar royal measures in 1683-84 and 1689-97. In 1689 it refused to seize the goods of French merchants until the monarchy agreed in 1693 to sidestep legal obstacles by substituting sequestration for 'donations'. The Diputación's attitude thus allayed punitive measures and favoured the continuity of French trade. ${ }^{41}$

Significantly, legal resistance to royal measures was far more determined in Aragon than in Catalonia or Valencia, especially in 1683-84 and 1689-97. The Diputación of Valencia had always had more limited political powers and funding, while the Spanish monarchy had increased its political control over the Catalan Diputación, which was in any case hobbled by bankruptcy in the second half of the seventeenth century. ${ }^{42}$ After a last protest to the viceroy in 1675 , the Catalan Diputación fell silent in its opposition to royal orders prohibiting trade with France. Furthermore, the military occupation of Catalonia in 1641-52 and in 1694-97, and the annexation of the Roussillon district by France in 1659 persuaded the local elites to 
cooperate with the monarchy in the last three decades of the seventeenth century. Having begun slowly to recover after 1680, the commercial bourgeoisie and textile guilds of Barcelona supported trade bans and reprisals against the French, whom they saw as competitors in the regional market. ${ }^{43}$

However, the Aragonese Diputación also had to defend domestic free trade against other regional institutions. It took legal action in the Corte del Justicia several times in the seventeenth century to contest measures adopted by the craft guilds and municipalities to protect local artisans and merchants from French competition by creating barriers such as quality controls, new taxes and official prices for foreign goods. The municipal officials of Saragossa were especially proactive in this regard, even banning the entry of foreign woollens, silks, and gold and silver brocade into the capital in 1675, a regulation which was immediately struck down by the Diputación. These legal actions protected the landed interests of the church and the nobility. These agrarian elites appreciated the benefits of trade with France, which offered them the opportunity both to sell their own output and to consume competitive French goods. ${ }^{44}$ As we shall see below, however, the interests of the towns and the agrarian elites clashed at every Parliament held in the seventeenth century, and the search for new revenue sources for the royal treasury conditioned all proposals for trade reform.

\subsection{Royal taxation and protectionism (1626-50).}

Despite the Diputación's legal victories, the increasing tax demands made by the monarchy at the Cortes of 1626 resulted in a further hike in Aragonese customs duties. Import and export duties were doubled from 5 to 10 per cent of value between 1628 and 1642 to pay royal subsidies. In the interest of landlords and the recipients of rents, who were numerous among the clergy, nobility and even wealthier citizens, export duties on the main commodities and foodstuffs (wool, wheat and meat) were set at a lower rate of around 5 per cent, however. This rate was also applied to import and export duties on other essential foodstuffs like wine and fresh fish in order to hold down retail prices, although rising olive oil exports were taxed at 10 per cent to counteract widespread black-marketeering at the border. Against the opinion of the Diputación, the Cortes also banned the export of gold and silver coins to other Spanish territories or abroad. ${ }^{45}$ 
Raising tariffs was a risky strategy given the sharp contraction in regional trade. After peaking in 1606-11, the customs revenues obtained by the Diputación fell sharply in 1612, because the expulsion of the Moriscos in 1610 had hurt the credit market and depressed domestic investment, output and demand (see Figure 1). Aware of the shortage of capital affecting the textile guilds, itself a result of these processes, the Cortes of 1626 prohibited the import of gold and silver brocade, silk and woollens from abroad, not including tapestry work or linens. The Parliament thus changed its traditional free trade policy despite the objections of the Diputación, which protested that most imported woollens and silks came from sovereign Spanish territories like Catalonia, Valencia and Flanders. ${ }^{46}$ However, the transit of goods bound from one Spanish territory to another through Aragon was permitted in order cushion the impact of the ban on imports from Castile, Navarre, Valencia and Catalonia, and on the Diputación's own revenues (see map). An additional tax of 5 per cent of value was imposed for the fifteen-year term of the royal subsidy on locally produced woollens, silks, and gold or silver brocade, which were now protected by the import ban. Also, the municipalities' authority to set the retail prices of textiles in local markets was confirmed. $^{47}$

The protectionist policies demanded by the textile guilds of Catalonia in 1620 and 1630 came to nothing, because no Parliament was held in the principality, but similar proposals triumphed in Aragon because they offered the means of paying higher state taxation. The Parliament of Valencia also raised customs duties on imports by 5 per cent in 1626, although it was able to exempt grain and meat imported from Aragon, having granted a smaller subsidy. After new municipal taxes had been limited to the production of wine, it only became necessary to tax foodstuffs and textiles in Valencia to pay for troops to fight in Catalonia and to meet the subsidy of 1645. Imports of foreign cloth continued to be permitted to secure the kingdom's customs revenues. ${ }^{48}$

Black-marketeering flourished in Aragon between 1628 and 1642, driven by the new taxes on trade and textiles production, which pushed up costs and undermined the competitiveness of local manufactures. Neither of these protectionist measures prevented imports of French manufactures in the second quarter of the century, whether by smuggling, under import licences granted by royal institutions, or by the fraudulent claim that goods were destined for sale in other Spanish dominions. The Diputación 
itself facilitated this process by seeking authorisation from the Corte del Justicia de Aragón (in 1630, 1633 and 1638) to seize, mark and sell illegal goods rather than burning them as the protectionist party demanded. The combination of blackmarketeering and royal efforts to prevent Aragonese trade with France substantially lowered the revenues of the Diputación between 1635 and 1640 (see Figure 1). ${ }^{49}$

The merchant class, formed by wealthy citizens and petty nobles, insisted at the Cortes of 1645-46 on banning the import of foreign fabrics and the export of native currency, and on strict supervision of commercial transactions in Aragon. Several Saragossa guilds also advocated such measures to prevent the expansion of French commerce. Despite support for these proposals among the citizens, pressure from the high nobility and the clergy led the Parliament to repeal the ban on textiles imports, accepting the failure of its protectionist policy. ${ }^{50}$ However, export and import duties were raised to 13 per cent of value between 1647 and 1650 to pay for regional militias recruited to fight in Catalonia. This hike in customs duties sought to profit from the growth in trade generated by the presence of the Court and the royal army in Aragon during the conflict. The moderate import/export duty of around 5 per cent of value on wool and certain essential foodstuffs set in 1626 was maintained, as was the ban on exports of gold and silver approved with one eye on France as the main destination for outflows of Aragonese and Castilian coins. ${ }^{51}$

Despite increasing its revenues during the war in Catalonia, the Diputación was obliged to collect the new duties and the output tax on textiles itself, because rampant fraud and tax evasion put off the usual tax farmers. The increase in customs duties applied in 1647-50 compounded these problems by increasing transaction costs in the regional market. As a consequence, the revenues obtained by the Diputación fell by around 33 per cent over the third quarter of the seventeenth century, even though duties were again lowered to 10 per cent in 1651 . This was partly due to the contraction in trade after the Court and royal army left Aragon, and partly to persistent blackmarketeering and tax evasion (see Figure 1). ${ }^{52}$

4.3. Royal taxation and the trade debate (1674-1700) 
Against this background of commercial decline and legal confrontation, the trade policy debate only took shape in Aragon when the viceroy Don Juan José de Austria created the Junta de Comercio (Board of Trade) in Saragossa in 1674. This body was formed by delegates of the main representative institutions including the Corte del Justicia de Aragón and the Diputación, royal advisers and senior municipal officers of the city of Saragossa, and its mission was to seek solutions to the region's economic problems, chiefly French control of commercial transactions, industrial decline, the shortage of coinage and depopulation. ${ }^{53}$ The numerous written depositions submitted to the Junta de Comercio by the Aragonese arbitristas (political economists) reflect two opposing lines of economic thinking on trade policy. One of these, backed by the Diputación, favoured removing all impediments to trade and suppressing some tariffs, such as royal and private tolls. The Diputación had urged this reform on the Spanish monarchy since the early seventeenth-century, especially at the Parliament of 1626, although it supported the continuation of customs posts on Aragon's borders and in the large towns because they provided its main source of revenues. ${ }^{54}$ However, the Aragonese towns and, in particular, the city of Saragossa supported the import ban and tighter municipal control over local transactions under pressure from urban artisans and merchants, whose main concern was foreign competition. Contributing to this debate, the free-trade advocate José Marcelo de Sotomayor Uribe penned his Discurso foral, jurídico y politico en defensa del libre comercio in opposition to the municipal statute passed in Saragossa in 1675 banning the sale of imported textiles in the city. However, the numerous champions of protectionism gained greater influence in the Junta de Comercio and in the Cortes of 1677-78, where a flurry of proposals from citizens, minor nobility and artisans were also presented. Led by some among the infanzones, low-ranking gentry who engaged in trade and manufacturing, the guilds even sought in 1677 to influence the decisions of the Parliament by organizing protests in the streets of Saragossa and packing meetings of the petty nobility with their supporters. ${ }^{55}$

This debate was conditioned by French dominance in trade and manufacturing, which became firmly established in Aragon after an earlier ban on textiles imports was repealed in 1646. The French were accused of causing poverty and depopulating the region by pushing aside Aragonese traders, carrying off the silver coinage, ruining local artisans by importing their own manufactures, and exporting the wool and silk needed by weavers, which they could obtain cheaply because they controlled trade. In response, 
artisans, merchants and arbitristas all petitioned the Junta de Comercio and the Cortes of 1677-78 to ban imports of French goods. To ensure compliance, they urged that the municipalities should be allowed to supervise local markets, set prices and prevent the sale of any goods that were not in conformity with Aragonese standards. They also sought changes in the law to require wool and silk producers and merchants to sell their goods preferentially to local municipalities and natives rather than to foreigners, at the same time pressing for the enforcement of export bans and further hikes in export duties. Antonio Cubero Sebastián, for example, recommended to the Junta de Comercio in 1674 that exports of wool should be taxed at 10 per cent of value. Nevertheless, some protectionist thinkers advised lowering tolls and duties on the export of manufactured goods in order to regenerate textile production and trade. José Gracián Serrano even defended the abolition of all tolls and customs duties in Aragon at the Cortes of $1678 .{ }^{56}$

The main problem for the protectionist party was the creation of new taxes to compensate the Diputación for the loss of revenues implicit in the proposed ban on textiles imports and reduction in customs duties. The guilds proposed a municipal poll tax that would include the nobility and clergy. However, other social groups considered that the tax should be paid by textiles workers only, as they were the main beneficiaries of the ban. ${ }^{57}$ The fiscal problem was even worse at the Cortes of 1677-78, because new revenue sources were needed to pay the royal subsidy given the dire financial straits of the municipalities. Despite losing revenues and local control over markets, the citizens agreed to raise the tax on exports of wine and oil to 2 per cent of value and to establish regional monopolies over luxuries like tobacco, paper, playing cards, sugar, cocoa, pepper and spices. Though this initial proposal was approved, the high and low nobility suggested replacing the proposed new monopolies with higher customs duties or taxes on textiles production, in line with the policy adopted by the Cortes in 1626 and 1646. For its part, the church advocated reducing the Diputación's debt only by cancelling loans or lowering interest rates. Finally, opposition from the agrarian elites to any increase in export duties on commodities and the difficulty of establishing monopolies in Aragon meant that the proposals of the nobility carried considerable weight with the Parliament. $^{58}$

Designed as a reaction against French control of trade, the protectionist policy adopted in 1678 sought to appease both the Spanish monarchy and the main social groups able to influence the Cortes. Imports of woollens, silks, and gold or silver 
brocade, peddlers' wares and trinkets manufactured abroad were banned in the interests of urban merchants and artisans. At the urging of the protectionists, this ban was extended to all Spanish territories including Castile in a bid to prop up local textile production and prevent French wares from entering Aragon via alternative routes, and it also included foreign goods in transit to other destinations. In order to compensate the Diputación for the resulting loss of customs revenues, out of which royal subsidies were paid, both import and export duties were set at 20 per cent of product value. However, export duties on the main Aragonese commodities (wool, cereals, wine, meat and olive oil) were left unchanged to stimulate production, satisfying both landlords and tenants. As additional compensation for the Diputación, another 5 per cent of value was imposed on locally produced woollens, silks, gold and silver brocade, and tanned hides. However, duties on fabrics were lifted to promote exports. The interests of Aragonese livestock farmers prevented any restrictions on the wool trade, although the Parliament did ban exports of raw silk in order to foster craft production in Aragon. ${ }^{59}$

Similarly, the financial needs of the monarchy prevented any moves to mitigate the foreseeable rise in transaction costs caused by the new taxes and duties in the regional market. Although the Cortes voted to abolish royal tolls, which added 5 per cent to transit costs, the enormous compensation demanded by the royal treasury (14,500 libras per annum) frustrated application of this measure. Undeterred, the Cortes immediately ordered a commission of senior municipal officials to assess the value of foreign and domestic goods in each local market and prevent excessive price rises, especially for textiles. The Parliament also prohibited the inclusion of any hidden taxes in assessed prices in order to facilitate regional trade. ${ }^{60}$

To the chagrin of the protectionist party, the prohibition of textiles imports was soon circumvented by fraud and smuggling. ${ }^{61}$ Already burdened by output taxes, native textiles actually lost share in the regional market to French products even though the ban drove up retail prices. Some Aragonese merchants firmly opposed the protectionist policy, observing in 1684 that the ban had raised the price of French textiles in the regional market by 20 per cent since $1678 .{ }^{62}$ Many impoverished textile workers moved to Valencia to carry on their trade while others drifted away in search of work. ${ }^{63}$ Exports of commodities to Catalonia, Valencia and France remained strong, however, as prices continued to fall and institutional barriers to exports of wheat and oil were gradually 
removed in the second half of the seventeenth century, making Aragonese produce increasingly competitive. ${ }^{64}$

The increase in customs duties and their application to goods in transit to other territories caused serious upset in the regional market. Many foreign merchants avoided Aragon, choosing other trade routes instead. Furthermore, other Spanish realms affected by Aragonese protectionism responded in kind. Regional imports of Aragonese wine and fabrics were banned by the Navarrese Parliaments of 1677-78 and 1684-85, and the Spanish monarchy imposed legal barriers in Castile in 1682 (see the map). ${ }^{65}$ These trammels not only hindered domestic and foreign trade, but also encouraged blackmarket practices. The result was to depress the Diputación's revenues in 1679-83 below the level of 1628-50, despite the sharp hike in tariffs (see Figure 1).

Foreseeing difficulties ahead, the Cortes of $1677-78$ provided for an assembly to be formed by two delegates from each of the four estamentos to review the new trade policy after six years. When protectionism failed to halt the decline of regional manufacturing, the assembly delegates and their advisers met in 1684-86 to negotiate with royal delegates, sparking renewed debate among the Aragonese arbitristas. Notably, Diego José Dormer addressed his Discursos históricos-politicos to the assembly in 1684. Like Sotomayor in 1675, Dormer based his arguments on fueros approved by the Cortes in 1247, 1283, 1325, 1348, 1456, 1461 and 1528, which protected the free movement of goods and prohibited the creation of new tolls or imposts in Aragon, claiming that all of the temporary restrictions on trade voted by the Cortes in the past had ended in failure. He contended that Aragon's economic decline was due rather to the weakness of the region's commercial bourgeoisie and the scarcity of skilled and industrious artisans than to the activities of the French. On these grounds, he proposed the repeal of all import bans and municipal or guild controls on domestic transactions to encourage trade, and the abolition of royal tolls, regional customs posts and output taxes on textiles. The monarchy and the Diputación would be compensated out of the revenues generated by a regional salt monopoly and a municipal tax similar to that applied to meet royal subsidies in 1647-50. Initially based on the census of 1646, the local distribution of the tax would be revised every ten years after a new census had been taken. ${ }^{66}$ 
Supported by many of the towns and the craft guilds, the protectionist party hardened its opposition to French trade before the assembly of the estamentos held in 1684-86. In a memorandum submitted in 1684, José Tudela Tarazona advocated closing down all trade with France, and José Gracián Serrano Manero responded to Dormer by arguing for an extension of the trade ban to the neighbouring Spanish domains. Given these territories' very limited exports of goods to Aragon, this proposal would have had little impact on them, but it might have prevented fraudulent imports of French goods. Like Dormer, Tudela and Serrano believed that the hike in customs duties and the tax on textiles production approved in 1678 hurt the economy, and they too recommended abolishing all customs duties and tolls in Aragon. Furthermore, the fiscal compensation offered to the Diputación, the monarchy and private parties would not include any tax on domestic textiles production. As he had done at the Parliament of 1678, Serrano urged the 1684 assembly to share the burden of royal taxes among the municipalities using the traditional methods, and to tax essential foodstuffs like bread. Both Serrano and Tudela insisted on maintaining the municipal right, approved in 1678 , to set retail prices in local markets. ${ }^{67}$

Shocked by the demands of the more radical protectionists, some regional authorities sought to ease the pressure. In 1684 the city of Saragossa punished a number of artisans for trying to coerce representatives of the clergy into voting in favour of laws discriminating against French residents in Aragon, and in the same year the Justicia de Aragón took legal action to prevent the petty nobility from harassing the other estates. Despite initial support for protectionism among the gentry and citizens at the assembly of 1684-86, traditional free trade policies eventually triumphed thanks to combined pressure from the agrarian elites and the monarchy, which was keen to foster Aragonese trade with Castile and the other Spanish realms. The monarchy reaffirmed this policy in Catalonia in 1699 and 1700 when the viceroy turned down petitions from the Barcelona guilds to ban exports of domestic silk and wool, and imports of any fabrics not manufactured in the region. ${ }^{68}$

The assembly finally removed the ban on textiles imports in 1686, maintaining the prohibition on pedlars' wares and trinkets. Customs duties were again set at 10 per cent of the value of goods in general and remained unchanged for exports of the main Aragonese commodities. Unrestricted exports of raw silk were again allowed except in 
times of scarcity, but a reciprocal ban was imposed on wine imported from the neighbouring Kingdom of Navarre. The assembly also removed the output tax imposed in 1678 to foster the recovery of textiles manufacturing, instead imposing a 5 per cent tariff on exports. Legal impediments to the sale of fabrics manufactured in Aragon in local markets were also abolished. Accordingly, the artisans' right to examine foreign and domestic goods sold in their town and village markets was subjected to stricter municipal control in order to prevent the rejection of merchandise on spurious quality grounds. However, the municipal commissions created in 1678 continued to assess the prices of both domestic and foreign fabrics sold in Aragon. ${ }^{69}$

This trade reform reduced the Diputación's revenues by lowering customs duties, which forced the Spanish monarchy to accept a 40.6 per cent cut in the annual royal subsidy from 1686 to the end of the payment period. In return, the moderation of duties was expected to facilitate trade not only in Aragon but in the whole of north-eastern Spain. The removal of the tolls approved by the Cortes of 1678 required similar fiscal cooperation. All of the tolls (royal, seigniorial, municipal and others) created in Aragon since the Middle Ages were finally abolished and the number of customs posts on the borders was reduced. As a result, 22.15 per cent of the new royal subsidy was applied to pay annual compensation for the suppression of tolls, consisting of 6,000 libras for the royal exchequer (41.4 per cent of the amount requested by the monarchy in 1678) and around 1,420 libras for other persons and institutions affected. ${ }^{70}$

Favoured by the expansion of demand driven by the recovery in Aragon's population in the last two decades of the seventeenth century, this reform slowly helped revitalise regional trade and the Diputación's revenues in 1696-1701 finally returned to something like the levels of 1668-77 (see Figure 1). Goods again began to move through the region in transit to other territories, and business returned to legal markets. The effects on regional output were uneven, however. Despite the repeal of the output tax on textiles manufacturing, the industry remained uncompetitive and its decline intensified. Though textiles output actually grew at a moderate pace in the large towns immediately after 1730 on the back of rising domestic consumption, it never recovered its pre-1650 level. However, unrestricted imports of fabrics provided French merchants with the wherewithal to buy ever more Aragonese commodities, driving growth in both output and exports, although this gradual expansion was not down to the conquest of 
new markets. In view of scant Aragonese demand for their own manufactures and raw materials, both Castile and above all Navarre maintained legal and administrative barriers to imports and the transit of Aragonese goods until the end of the seventeenth century. Nevertheless, the region's products could still be sold in Catalonia, Valencia and France, which remained much more important markets than Castile. ${ }^{71}$

In short, the reform intensified the outcomes of product specialisation and trade complementarity resulting from the gradual restructuring of the regional economy both in Aragon and in north-eastern Spain as a whole, in a process which lasted throughout the seventeenth century, though it gathered pace after 1650. The repeal of tariff barriers between the Crowns of Castile and Aragon decreed by the more centralizing Bourbon state in 1714-17 accelerated the process by facilitating the movement of goods. Dominated by French merchants until 1740, and then by the Navarrese until 1770, the Aragonese market was flooded with foreign fabrics, mainly from France. Catalan manufactures only took over after 1770, once the principality's merchants had won control of the main trade flows. ${ }^{72}$

\section{Conclusions}

As recent trends in Political History and Sociology have shown for the whole of early modern Europe, the progress of the "fiscal state" under the multiple sovereignty of the Hapsburg monarchy in seventeenth century Spain was slow and difficult in regions enjoying high levels of autonomy like the Kingdom of Aragon. The monarchy met with determined resistance from the regional elites and representative institutions when it sought to ban trade between Aragon and France, which was crucial to the regional economy. By integrating the Aragonese elites into the state and colonial administration, however, the monarchy secured their acquiescence in more systematic and higher state taxation in the second quarter of the century, a critical period in Spain's struggle for European hegemony. Having reduced their contribution after the war of secession in Catalonia, these elites also agreed to the continuation of royal taxes in the last quarter of the century, albeit at a lower level, partly to obtain honours and permanent posts for Aragonese naturals in the state administration, although their aspirations were largely 
disappointed, but mainly because they needed a free hand to formulate trade policy via parliamentary legislation in order to remedy the region's economic problems.

The state's fiscal policy encountered some serious economic and institutional problems, which affected tax efficiency and aggravated undesirable outcomes with the result that it was applied patchily in a region undergoing both demographic and economic decline, and taxes combined parliamentary grants of regular subsidies running for decades with a raft of donations, loans and military levies raised from both private parties and institutions. The increasingly straitened finances of the municipalities and the Diputación, the institutions which had paid royal subsidies in the sixteenth century, posed a further problem. Furthermore, the distribution of the tax burden was complicated by the lack of up-to-date censuses until 1646-50, so that it fell most heavily on the capital. Meanwhile, rising municipal taxation of the main foodstuffs eroded the working capital, savings and self-financing capacity of the productive classes, while depressing disposable incomes among the population as a whole. The fiscal policy agreed with the regional elites in the Aragonese Parliament taxed trade and textiles output in 1626, 1646 and 1678 to mitigate these effects, but this option worsened the decline of regional manufacturing, raised transaction costs and generated serious imbalances in both domestic and foreign markets. These grave problems forced the monarchy to reduce taxes on trade in 1686 and to introduce new monopolies on salt and tobacco, which had a less pernicious impact on regional economic growth. Even so, the tariff barriers erected in Aragon after 1626 in response to state taxation lingered on throughout the century, and according to Epstein the situation was only corrected in 1714-17 when the new Bourbon monarchy abolished internal customs between the Crowns of Castile and Aragon as part of its drive to create a unified, national market.

Weakened by their infrequency and the conflicting political and economic interests of the estamentos, the Cortes reduced royal subsidies in 1678-97, but they proved unequal to the task of designing any more satisfactory fiscal and trade policies for the regional economy. The protectionist measures enacted in 1626 and 1645-46 ensured the collection of royal subsidies by taxing domestic manufactures and imported goods, but they failed to reactivate the textiles industry while raising transaction costs, and they exacerbated smuggling and unlawful practices until their eventual repeal in 1651 under pressure from the agrarian elites. The exceptional Parliaments convened in 
1677-78 and 1684-86 prompted intense debate on fiscal and trade matters in Aragon. However, the Cortes flatly rejected the creation of any new monopolies to lower or remove customs duties and tolls, as recommended by the Diputación and the arbitristas. Instead, taxes were raised on textiles production and imports of other foreign manufactures as the quid pro quo for a ban on textiles imports and transit goods. As in 1626 , the authority of the municipalities to set the retail prices of textiles and other foreign goods in local markets was reconfirmed. Overall, this policy hobbled trade throughout the north-east of Spain without actually preventing the decay of domestic manufacturing in Aragon, which forced the agrarian elites to negotiate with the royal delegates in 1684-86 in order to seek a reduction in the tax burden, the abolition of all tolls created since mediaeval times, and a relaxation of regional and local protectionism. These reforms lowered transaction costs, favouring gradual growth in farm output and trade throughout the region at the end of the century.

Finally, the more independent and consistent policy of the Diputación eventually succeeded in imposing more favourable economic conditions, generally based on customary laws and supported by the region's rentier elites. It also improved roads between 1560 and 1626 in order to foster trade. Furthermore, its significant contribution to state taxation between 1628 and 1656 sought not only to satisfy royal demands but also to alleviate municipal indebtedness and to protect the territorial integrity of the kingdom of Aragon. The Diputación thus guaranteed property rights and the transit of goods against interference not only from the monarchy, as North and Weingast explain, but also from regional institutions and groups throughout the seventeenth century. Finally, its lukewarm collaboration with the import bans on textiles imposed by the Cortes contributed to their eventual failure. At the cost of accepting French commercial and manufacturing predominance in Aragon, the Diputación's free trade policy encouraged increasing regional specialization in export-oriented agriculture after 1650, despite a chronic lack of investment. This restructuring slowly helped the Aragonese economy to recover, although growth was not strong enough to prevent its becoming ever more dependent on Catalonia in the eighteenth century, and the lag only intensified when internal customs were abolished in north-eastern Spain in 1714-17. In contrast, the recovery in manufacturing and trade which accompanied agricultural specialization in Catalonia towards the end of the seventeenth century was driven by the region's 
much more dynamic elites, who proved decisive in laying the foundations for long-run growth despite the decay of the principality's representative institutions.

\section{Acknowledgements}

This work is part of research project HAR2011-29036-C02-01, financed by the Spanish Ministry of Economy and Competition.

\footnotetext{
${ }^{1}$ Max Weber, Economy and Society (Berkeley, 1978); Joseph A. Schumpeter, The Economics and Sociology of Capitalism (Princeton, 1991), 99-140.

2 Among the sociologists, we may mention Charles Tilly, Coercion, Capital and the European States, A.D. 990-1990 (Oxford, 1990); Michael Mann, The Sources of Social Power (Cambridge, 1986); Brian M. Downing, The Military Revolution and Political Change: Origins of Autocracy and Democracy in Early Modern Europe (Princeton, 1992) and Thomas Ertman, Birth of the Leviathan (Cambridge, 1997). Key historians include Perry Anderson, Lineages of the Absolutist State (London, 1974); I.A.A. Thompson, War and Government in Hapsburg Spain, 1560-1620 (London, 1976); William Beik, Absolutism and Society in Seventeenth Century France (London, 1990) and Wolfgang Reinhardt (ed.), Power Elites and State Building (Oxford, 1996).

3 Patrick K. O’Brien, "The Political Economy of British Taxation, 1660-1815”, Economic History Review, XLI, (1988), 1-32; John Brewer, The Sinews of Power (London, 1989); Richard Bonney (ed.), Economic Systems and State Finance (Oxford, 1995) and The Rise of the Fiscal State in Europe, c. 12001815 (Oxford, 1999); Philippe Contamine (ed.), War and competition between States (Oxford, 2000); Jan Glete, War and the State in Early Modern Europe (London, 2002); Bartolomé Yun-Casalilla, Patrick K. O'Brien and Francisco Comín (eds.), The Rise of Fiscal States: A Global History, 1500-1914 (Cambridge, 2012).

${ }^{4}$ Douglass C. North, Structures and Change in Economic History (New York, 1981); Douglass C. North and Barry R. Weingast, "Constitutions and Commitment: Evolution of Institutions Governing Public Choice in seventeenth-century England", Journal of Economic History, XLIX, (1989), 803-832; J.L. Van Zanden, E. Buringh and M. Bosker, "The Rise and Decline of European Parliaments, 11881789”, Economic History Review, LXV, (2012), 835-861; S. R. Epstein, Freedom and Growth. The Rise of States and Markets in Europe, 1300-1750 (London, 2000), 13-37.

${ }^{5}$ See notes 2, 3 and 4.

6 Anna María Rao and Steinar Supphellen, "Power Elites and Dependent Territories" in Reinhardt (ed.), Power Elites, 79-99.

${ }^{7}$ Marie-Laure Legay and Roger Baury (eds.), L'invention de la décentralisation: noblesse et pouvoirs intermédiaires en France et en Europe, XVII ${ }^{e} X I X^{e}$ siècles, (Villeneuve d'Ascq, 2009).

${ }^{8}$ Emiliano Fernández de Pinedo, (ed.), Haciendas forales y hacienda real (Bilbao, 1990), 195-206; Ángel García Sanz and Felipe Ruiz Martín, (eds.), Historia de la Hacienda en España (siglos XVI-XX) (Madrid, 1991).

${ }^{9}$ See, for example, the articles published in Ius Fugit, 10-11 (2001-2002) on the Parliaments held in the Crown of Aragon in the sixteenth century.

10 José Antonio Salas, "La evolución demográfica aragonesa en los siglos XVI y XVII", in Jordi Nadal (ed.), La evolución demográfica bajo los Austrias (Alicante, 1991), 169-179; Diego José Dormer, Discursos históricos-politicos (Zaragoza, 1989, facsimile of the original printed in 1684), 129-133 and Library of the Spanish Royal Academy of History (hereafter LSRAH), Nasarre Collection, Manuscript 11-1-1, fos. 547r-562v. In this study, we have estimated 4.5 inhabitants per hearth to calculate the stable population living in Aragon during this period.

${ }_{11}$ Alejandro Abadía, La enajenación de rentas señoriales en el reino de Aragón (Zaragoza, 1998), $362-430$

12 José Antonio Mateos, "Municipal Finances in the Kingdom of Aragon in the Sixteenth and Seventeenth Centuries”, Journal of European Economic History, XXXVIII, 3 (2009), 483-487.
} 
13 José María Sánchez Molledo, Arbitristas aragoneses de los siglos XVI y XVII. Textos (Zaragoza, 2009), 49-50.

${ }^{14}$ José Ignacio Gómez Zorraquino, La burguesía mercantil en el Aragón de los siglos XVI y XVII (1516-1652) (Zaragoza, 1987) and Zaragoza y el capital comercial (Zaragoza, 1987).

${ }^{15}$ ADS, Manuscript 734, fos.276r-279r, 405r-408r.

${ }^{16}$ Luis Perdices and Jose María Sánchez Molledo (eds.), Arbitrios sobre la economía aragonesa del siglo XVII (Zaragoza, 2007), 253-266, 354-357, 476; Archive of the Diputación, Saragossa (hereafter ADS), Manuscript 722 , fo. $487 \mathrm{v}$.

${ }^{17}$ Gómez Zorraquino, Zaragoza.

18 Antonio Peiró, "Comercio de trigo y desindustrialización", in the conference proceedings Las relaciones económicas entre Aragón y Cataluña (siglos XVIII al XX) (Huesca, 1990), 49-50; ADS, Manuscripts 523, fos.215r-422r; 80, fos.2334r-2335r.

19 José Antonio Mateos, "Control público, hacienda municipal y mercado agrario en el reino de Aragón durante los siglos XVI y XVII”, Hispania, CCXXIII, (2006), 560-567.

${ }^{20}$ Gómez Zorraquino, Zaragoza, 86-88.

${ }^{21}$ Leonardo Blanco, La actuación parlamentaria de Aragón en el siglo XVI (Zaragoza, 1996), 67-69.

22 Ibid.; Pascual Savall and Santiago Penen, Fueros, observancias y actos de corte del reino de Aragón (Zaragoza, 1866) I, 475-476; II, 372-373.

${ }^{23}$ Ibid.

${ }^{24}$ Mateos, "Municipal finances" 467, 472-476; Gregorio Colás and José Antonio Salas, Aragón en el siglo XVI (Zaragoza, 1982), 42-44.

25 I.A.A. Thompson, "Crown and Cortes in Castile, 1590-1665", Parliaments, Estates and Representations, II, (1982), 29-45; Gregorio Colas and José Antonio Salas, "Las Cortes aragonesas de 1626: el voto del servicio y su pago", Estudios, LXXV, (1975), 99-110; Dámaso de Lario, "Cortes valencianas de 1626: problemas en torno al pago del servicio ofrecido", Estudis, 4, (1975) 115-127; John H. Elliott, The Revolt of the Catalans (Cambridge, 1963), 182-247, 326-552.

${ }^{26}$ Ibid.; José Antonio Salas, "La hacienda real aragonesa en la segunda mitad del siglo XVII" in José Ignacio Fortea y Carmen María Cremades (eds.), Política y hacienda en el Antiguo Régimen (Murcia, 1993), 499-507.

${ }^{27}$ Savall and Penen, Fueros, I, 256, 416, 455-458, 477, 497-498; II, 372-373; Colas and Salas, "Cortes aragonesas", 100-104. For a discussion of the offices and titles granted by Philip IV to the nobility of Valencia, see James Casey, The Kingdom of Valencia in the Seventeenth Century (Cambridge, 1979), 236240.

28 Enrique Solano, Poder monárquico y Estado pactista (1626-1652) (Zaragoza, 1987), 128-190; Xavier Gil, "Conservación y defensa como factores de estabilidad en tiempos de crisis: Aragón y Valencia en la década de 1640" in Antonio Simón et al., 1640: la monarquía hispánica en crisis (Barcelona, 1992), 56-65.

${ }^{29}$ Luis Guía, Cortes del reinado de Felipe IV. II. Cortes valencianas de 1645 (Valencia, 1984).

${ }^{30}$ ADS, Manuscript 451, fo.398r; Savall and Penen, Fueros, I, 474-476; II, 404.

${ }^{31}$ Mateos, "Municipal finances", 453-454.

32 Colas and Salas, "Cortes aragonesas", 114-115; Porfirio Sanz, Politica, hacienda y milicia en el Aragón de los últimos Austrias entre 1640 y 1680 (Zaragoza, 1997), 60-62, 168.

${ }^{33}$ Henry Kamen, La España de Carlos II (Barcelona, 1980), 544.

${ }^{34}$ Albrecht Von Kalnein, Juan José de Austria en la España de Carlos II (Lleida, 2001), 267-279.

${ }^{35}$ Savall and Penen, Fueros, I, 521-522; II, 400-402.

${ }^{36}$ Kalnein, Juan, 468-470.

${ }^{37}$ Savall and Penen, Fueros, I, 526-534.

${ }^{38}$ Mateos, "Municipal finances", 483-485.

39 Sanz, Política, 62-63, 176-202, 277-298; Antonio Espino "El esfuerzo de guerra de la Corona de Aragón durante el reinado de Carlos II, 1665-1700. Los servicios de tropas", Revista de Historia Moderna, 22, (2004), 26-58.

${ }^{40}$ Mateos, "Municipal finances", 458-464.

${ }^{41}$ Archive of the Crown of Aragon, Council of Aragon (hereafter ACA, CA), files 74, 76, 189, 594; ADS, Manuscripts 422, 424, 428, 433.

${ }^{42}$ Casey, The Kingdom, 232-234; Eduard Puig, Intervenció reial i resistència institucional: el control politic de la Diputació General de Catalunya $i$ del Consell de Cent de Barcelona (1654-1705) (Unpublished Phd dissertation, Barcelona, 2012), 86-130. 
${ }^{43}$ Eduardo Escartín, "La Capitanía General de Catalunya i lordre constitucional catalá”, Pedralbes, 13, (1993), 95-101; Andrea Ricci, Narcis Feliu de la Penya (1646-1712) i el seu temps (Unpublished Phd dissertation, Barcelona, 2013), 243-287.

${ }^{44}$ Dormer, Discursos, 23; ADS, Manuscripts 334, fos.78r-79r; 445, fos.127v, 152r, 304r-v, 341r-348r; 449, fos.511r-v, 578v; Municipal Archive of Saragossa, municipal minute books, 1674-75, fos.52v-64r.

${ }^{45}$ Savall and Penen, Fueros, I, 456-458, 464-468; II, 371-372.

46 José María Sánchez Molledo, Arbitristas, 40-49. This policy was supported by some arbitristas. José Francisco de Arpayón claimed in 1644 that the Parliament's ban on textiles imports into Aragon would restrict competition and raise the prices of locally produced stuff. See I. de Asso, Historia de la economía politica en Aragón (Zaragoza, 1983, facsimile of the original printed in 1798), 174.

${ }^{47}$ Savall and Penen, Fueros, I, 453-454; II, 371-372.

48 Lario, "Cortes valencianas", 126-127; Amparo Felipo "Servicios y donativos de la ciudad de Valencia a la monarquía durante la revuelta catalana", Studia Histórica. Historia Moderna, 32, (2010), 314-332.

${ }^{49}$ Dormer, Discursos, 17-23; ACA, CA, file 74; ADS, Manuscripts 429-430, fo.155r-v; 451, fos.268r, $329 \mathrm{v}-330 \mathrm{r}$;

${ }^{50}$ ADS, Manuscripts 451, fos.204r-205v, 265r-v, 268r, 326v-355v; 722, fos.487r-492r.

${ }^{51}$ Savall and Penen, Fueros, I, 474-476, 495-496.

${ }^{52}$ Sanz, Política, 158-160; ADS, Manuscript 468, fos.91v-92r; 181r-182v.

${ }^{53}$ Perdices and Sánchez Molledo (eds.), Arbitrios, 129-213; SNL Manuscript 9,825, fos.18r-20v.

${ }^{54}$ Sánchez Molledo, Arbitristas, 51, 121-122; Dormer, Discursos, 118-119.

${ }_{55}$ Pablo Desportes "Entre mecánicos y honorables. La elite popular en la Zaragoza del siglo XVII", Jerónimo Zurita, 75, (2000), 65-68.

${ }^{56}$ Perdices and Sánchez Molledo (eds.), Arbitrios, 132, 143-144, 165-166, 216-218, 263-264; ADS, Manuscripts 580 fos.124r-131r; 734, fos.1345r-1349v; SNL, VE 25-9, VE 28-77, VE 180-40, VE 205-40.

${ }^{57}$ Ibid.

${ }^{58}$ Sanz, Política, 330-333; ADS, Manuscripts 555, fol. 1085r-1086v; 734, fos.845r-846v, 1165r-v, 1169r-v 1434r-1437r; 2419r, 2557r-2264v, 2626r-2627v; SNL,VE 25-10. The available fiscal options to avoid the introduction of monopolies were defended in these Cortes by protectionist thinkers like Antonio Cubero Sebastián and Pedro Borruel.

${ }^{59}$ Savall and Penen, Fueros, II, 400-407.

${ }^{60}$ ADS, Manuscript 580, fos.125r, 2317r; 734, fos.1347v-1348r; Savall and Penen, Fueros, II, 407408.

${ }^{61}$ ADS, Manuscripts 576, fo.118r.; 580, fos.128v, 392r-393r, 460r-467v, 2316v.

${ }^{62}$ SNL, VE 28-45.

${ }^{63}$ Sánchez Molledo, Arbitristas, 180-182.

${ }^{64}$ Mateos, "Control público", 566-567, 578-582.

${ }^{65}$ Dormer, Discursos, 26-27; ADS, Manuscript 580, fo.2317r-v.

${ }^{66}$ Ibid., 1-152. Dormer's economic ideas are discussed in Robert S. Smith, "Spanish Antimercantilism of the XVII ${ }^{\text {th }}$ century: Alberto Struzzi and Diego José Dormer", Journal of Political Economy, XLVIII, (1940), 401-411.

${ }^{67}$ Perdices and Sánchez Molledo (eds.), Arbitrios, 395-460, 475-523; ADS, Manuscript 580, fos.124r131r; SNL, VE 17-18, VE 217-30.

${ }^{68}$ ADS, Manuscript 576, fos.117r-126r, 602r-605v; Desportes, “Entre mecánicos...”, 70-73; Ricci, Narcis Feliu, 618-620.

${ }^{69}$ Savall and Penen, Fueros, I, 527-532.

${ }^{70}$ Ibid., I, 532-534; II, 426-436; ADS, Manuscript 580, fos.133r-134r, 3907v-3910v.

${ }^{71}$ Mateos "Control público", 563-568.

72 Peiró, "Comercio", 51-57. 